\title{
Differences and similarities in local ecological knowledge about rays among fishers, residents, and tourists
}

\author{
Ricardo Franco Freitas ${ }^{1,4 *}$, Lucas Peixoto Machado ${ }^{1}$, \\ Renato Hajenius Aché de Freitas ${ }^{1,2}$ and Natalia Hanazaki ${ }^{1,3}$
}

\begin{abstract}
Ray species have been globally threatened due to high fishing pressure and habitat loss. In southern Brazil fisheries, despite many ray species are protected by law and usually non-targeted species, they are captured along with commercially important species. However, as in all of Brazil, there is evidence that rays are consumed, that is, there is a demand for meat from these animals, which intensifies the risk of extinction. Marine ethnobiology is an alternative approach to better understand these organisms, considering the traditional empirical knowledge of fishers and local communities. Our objective is to evaluate the knowledge of local residents, fishers, and tourists about the occurrence, distribution, reproduction, and feeding of ray species and also ray consumption among them. We hypothesized that fishers and locals have a deeper ecological knowledge about rays than tourists, and fishers should know more than residents. Individual interviews were conducted for three consecutive days at Armação beach, Florianópolis, Brazil. We asked people about ray biology and ecology based on questionnaires. Each respondent was categorized into three groups: fishers, locals, and tourists; and ranked according to an index of ecological knowledge of rays. The fishers had greater knowledge about rays, followed by residents and tourists. Additionally, fishers and locals consume rays, even the trade is prohibited locally, evidencing the need for legal enforcement. The fishers' knowledge may be essential for management of fish stocks, contributing to sustainable fishing and species conservation. In contrast, the tourists' lack of knowledge evidences the need to raise awareness of these animals.
\end{abstract}

Keywords: Rays; Marine Ethnobiology; Local Knowledge.

1 Programa de Pós-Graduação em Ecologia, Universidade Federal de Santa Catarina, Campus Trindade s/n, Florianópolis, SC, 88970-000, Brazil

2 LABITEL - Laboratório de Biologia de Teleósteos e Elasmobrânquios, Departamento de Ecologia e Zoologia, Universidade Federal de Santa Catarina, Campus Trindade s/n, Florianópolis, SC, 88970-000, Brazil

3 ECOHE - Laboratório de Ecologia Humana e Etnobotânica, Departamento de Ecologia e Zoologia, Universidade Federal de Santa Catarina, Campus Trindade s/n, Florianópolis, SC, 88970-000, Brazil

4 CEPSUL - Centro Nacional de Pesquisa e Conservação da Biodiversidade Marinha do Sudeste e Sul, Instituto Chico Mendes de Conservação da Biodiversidade/ICMBio, Itajaí, SC, 883401-445, Brazil

* Corresponding author $\bowtie$. E-mail address: RFF (freitasricardof@gmail.com)), LPM (lucas.peixoto@acad.pucrs.br),

RHAF (renato.freitas@ufsc.br), NH (natalia.hanazaki@ufsc.br) 


\section{SIGNIFICANCE STATEMENT}

This study shows that the rays are perceived and consumed by fishers, residents, and tourists in different proportions and this consumption can contribute to impact the reduced populations of endangered species. Our results show the need for legal enforcement to mitigate this decrease and actions of these non-target species to raise public awareness about the problem. Lastly, the integration between fishers and the academic community may result in major advances for conservation and management plans for this group of species on the Brazilian coast.

\section{INTRODUCTION}

Rays, including skates, belong to the subclass Elasmobranchii, as well as the sharks. They have a cartilaginous skeleton and true bones where can be found at the bases of dermal teeth and denticles (Castro 1983). Globally, there are approximately 1112 species of elasmobranchs, and among them, 633 species are rays (Last et al. 2016). In Brazil, the number of ray species is about 70 (Rosa and Gadig 2014).

Many ray species are characterized by slow growth, late sexual maturation, and low fecundity compared to bony fishes (Stevens et al. 2000). These animals are among the major marine mesopredators, and they promote important links between upper and lower trophic levels, playing an essential role in the food chain (Ellis et al. 1996; Vaudo and Heithaus 2011). Due to these characteristics, the populations have limited potential to recover from overfishing and bycatch and still suffer population size reduction because of high pollution levels and habitat destruction (Camhi et al. 2009; Musick 2005). Several ray species are threatened, and 539 species are included in the International Union for Conservation of Nature and Natural Resources (IUCN) Red List of Threatened Species (Camhi et al. 1998; IUCN 2010). Nowadays, 24 out of 70 ray species cannot be captured and traded in Brazil (Brasil 2014), that is in line with $35 \%$ of the ray species in Brazil are threatened with extinction, with about $7 \%$ critically endangered (IUCN 2014).

In southern Brazil fisheries, rays usually are nontargeted species, though they are common (Costa and Chaves 2006; Dias-Neto 2011; Vooren and Klippel 2005), and the catches occur along with commercially important species such as flounders (Paralichthys spp.), whitemouth croaker (Micropogonias furnieri) and weakfishes (Cynoscion spp.). In Santa Catarina, gill fishing accounts for about $43 \%$ of elasmobranch landings, including rays and sharks, and the other modalities (different types of trawlers) for $57 \%$ (SBEEL 2005). However, there is a difficulty in managing the stocks of these cartilaginous organisms because crucial information about basic biology and population dynamics are scarce (Aguiar and Valentin 2010; Heithaus et al. 2008; Palmeira 2012; SBEEL 2005). Alternative approaches can help better under- stand these marine organisms, such as marine ethnobiology, which focuses on studies of the relationships between human societies and marine biotic communities of ocean ecosystems (Thaman 1994). One of these human groups is the populations of fishers and residents of coastal regions with a close relationship with nature, related to their socio-cultural, religious, and economic reproduction, with empirical knowledge traditionally transmitted (Diegues et al. 2000; Pereira and Diegues 2010). In ethnoecology studies, the concept of Local Ecological Knowledge is widely used, being a set of accumulated beliefs and knowledge about the environment acquired through observation and direct experience, passed through generations (Berkes and Folke 2000). Several contributions to the ecological understanding of marine species are based on ethnobiological or ethnoecological approaches (e.g., about diet and reproduction of a particular group such as the snappers/Lutjanidae, Begossi et al. 2011; or about ecology of targeted fish species and possible changes in stocks, Martins et al. 2014, 2018), and environments (Begossi et al. 2012; Peterson et al. 2019). However, most of these studies focused on teleosts, and only a few analyzed sharks (e.g., Barbosa-Filho et al. 2014, 2021; Carvalho et al. 2018; Santos et al. 2019) and none about ethnobiological knowledge of rays, other than the consumption of rays (Bornatowski et al. 2015). Due to the limited number of published academic information on rays in Brazil and the lack of studies in southern Brazil with this approach, our objective is to evaluate the knowledge of the population of local residents, fishers, and tourists about the occurrence, distribution, reproduction, and feeding of ray species.

Thus, the ethnobiological approach allows for a dialogue and exchange between academia and traditional and local communities (Kimmerer 2002; Santos et al. 2019). These studies should also respect local culture and recognize the community's contribution without the imposition of the researcher's ideas, as well as the use of appropriate language and respect respondent dynamics (Hanazaki and Freitas 2011). Considering that locals and fishers have higher frequency of contact with marine resources, we hypothesized that the locals and fishers have more in-depth ecological knowledge about the rays than tourists, and fishers should know more about the rays than the res- 
idents.

\section{MATERIAL AND METHODS}

\section{Study site}

This study was carried out at Armação beach in Florianópolis, Southern Brazil (Figure 1). Armação beach is a prominent neighborhood with traditional fishers within Santa Catarina Island, where Florianópolis is located. Armação was chosen due to this particular combination of a high concentration of artisanal fishers at one spot (an area in the southern part of the beach where fishing vessels are concentrated), the presence of local inhabitants, and the stable presence of tourists all over the year, although more concentrated during summer season and holidays. Unlike fishers, tourists and locals were found in different places of this neighborhood. According to the 2010 Demographic Census (IBGE 2011), the population of this neighborhood had around 2837 inhabitants, comprising $51.39 \%$ women and $48.61 \%$ men.

\section{Data collection}

Individual interviews were conducted for three consecutive days in November 2016, with an effort of about 8 hours per day. We approached all people found along the busiest streets and highways of Armação beach (including the area with fishing vessels) (Figure 2), and after explaining the objectives of the research, we individually asked for free and informed consent. This research was submitted and approved by the Ethics Committee of Research with Human Beings of Universidade Federal de Santa Catarina (CEPSH) under the number 52308116.9.0000.0121.

For the interviews, we used a protocol with open and closed questions (Table 1) based on structured questionnaires (Porcher et al. 2020). We asked questions about the interviewee's profile and ray biology and ecology (such as reproduction, feeding, and area of occurrence). We did not interview people who were relatives or lived in the same house. After the interviewees' acceptance to participate in the study, their answers were transcribed at the time of the interview. Question 6 was performed showing the ray egg

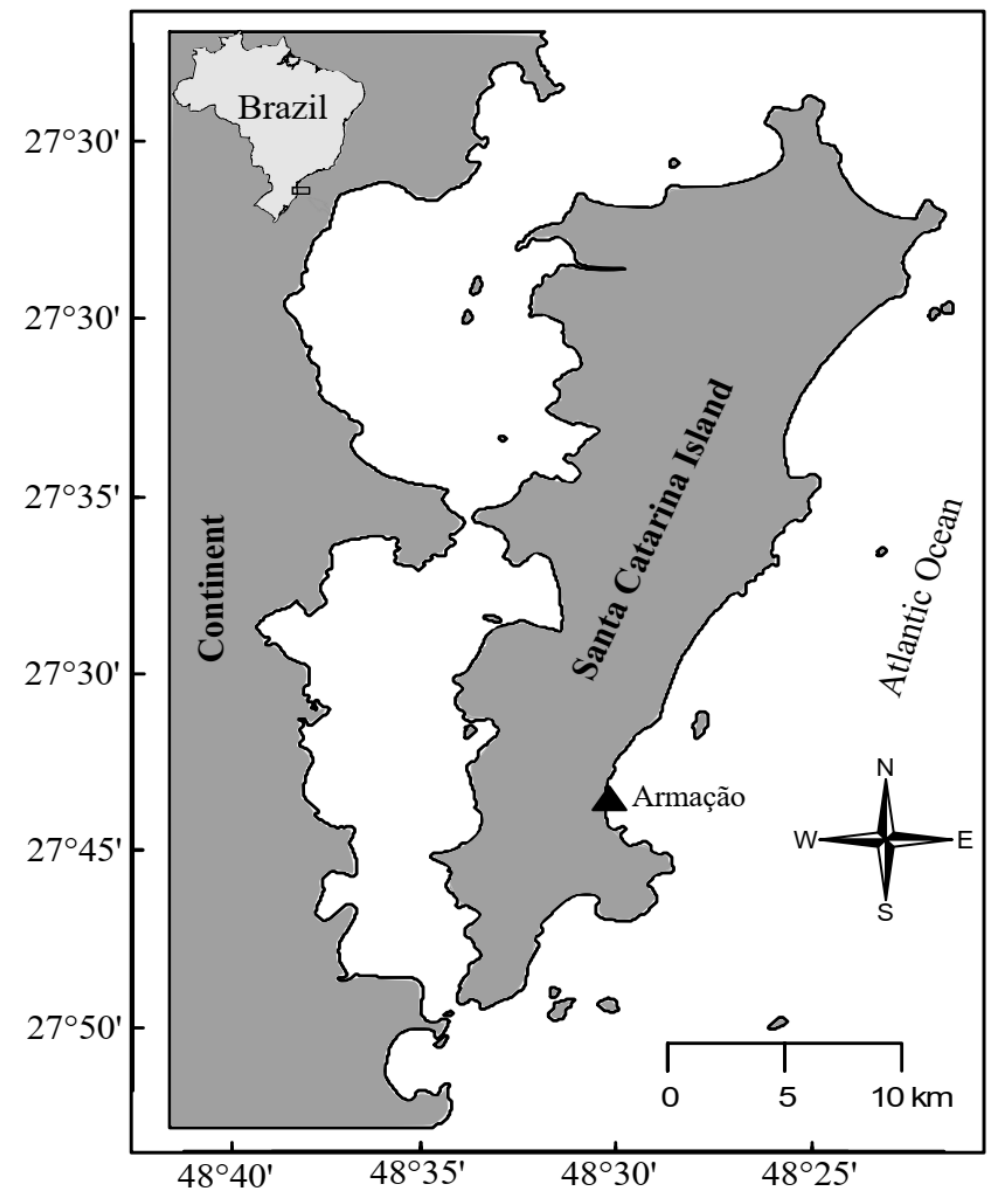

Figure 1. Map of Santa Catarina Island showing the neighborhood (Armação beach) where we carried out this study. 


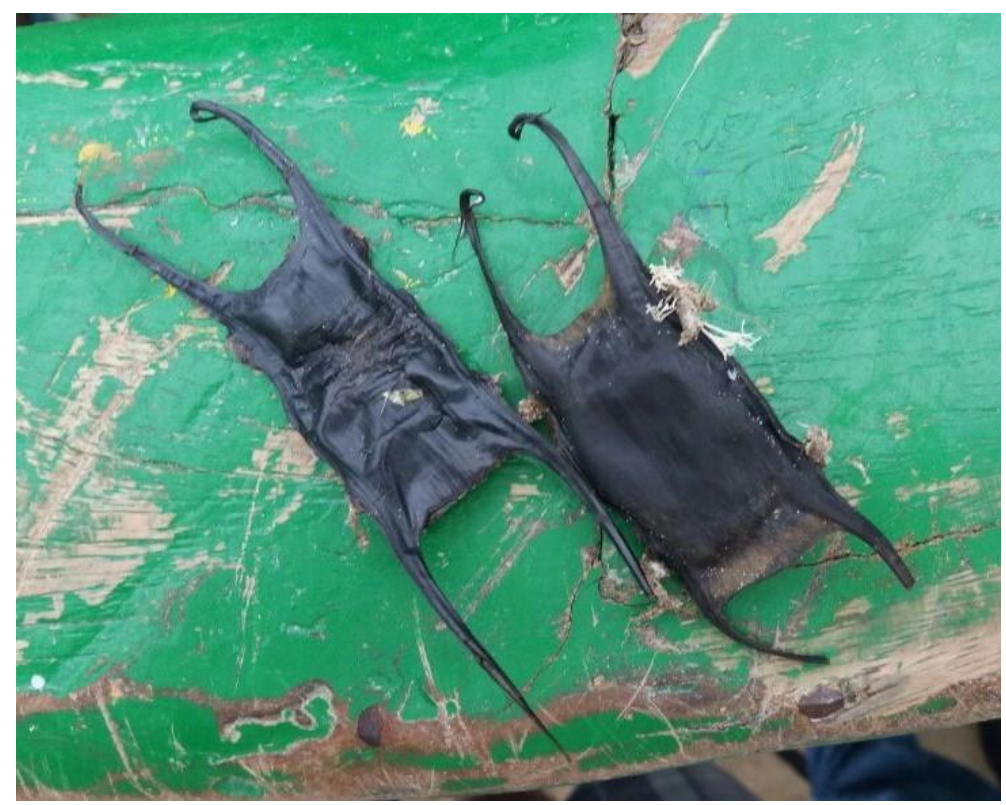

Figure 2. Ray egg capsules used during the interviews in Armação beach. Photo: Renato H. A. Freitas.

Table 1. The questionnaire used in interviews. The question numbers 5.1 to 5.5 were only asked if the answer of question 5 was "yes".

\begin{tabular}{lll}
\hline \hline Number & Question & Answer \\
\hline \hline 1 & How old are you & \\
2 & How it is your professional occupation & \\
3 & How often do you come to Armação beach? & Armação ( ) Others ( ) \\
4 & Where do you live? & Yes ( ) No ( ) \\
5 & Do you fish? & \\
5.1 & Is it professionally or for recreation? How often? & Yes ( ) No ( ) \\
5.2 & How do you fish? & \\
5.3 & Do you fish, or have you ever fished rays? Which species? & \\
5.4 & Do you find rays or ray eggs in the fishing net? & \\
5.5 & How often do you find it? & \\
6 & Do you know, or have you seen this structure (at that moment, & Yes ( ) \\
7 & an egg capsule of rays was shown - Figure 2) on the beach? & \\
8 & Do you know what this is? & \\
9 & Do you know how many species of rays occur in Brazil? & \\
10 & Do you know how the rays reproduce? & \\
11 & Do you know how to differentiate between male and female? & \\
12 & Where do rays occur? & What do rays eat? \\
13 & Do you eat ray? & \\
\hline \hline
\end{tabular}

capsules for each interviewee (Figure 2). We divided the respondents into three groups: fishers, locals, and tourists. Regarding this last group, all the people who did not live in Armação were considered tourists. We asked additional open questions to fishers who mentioned rays, about morphological characteristics for each local name, to help in scientific identification. We showed ray pictures for the fishers in order to verify their local knowledge about these marine organ- isms. After that, we related the popular names cited by the fishers with their respective scientific species.

\section{Data analysis}

To check for scientific identification, we used fishers' descriptions and information from the literature (Bornatowski and Abilhoa 2012; Gomes et al. 2010; Hayata et al. 2018). To quantitatively analyze the 
level of ecological knowledge of the rays regarding the groups (local residents, tourists, and fishers), each person was ranked according to an index of knowledge, reaching values from 0 (no knowledge) to 5 (highest knowledge). We assume that this index allows for an objective comparison among groups of respondents, even with the caveat of oversimplifying the amount of knowledge each person has. The index was composed by affirmative answers to questions 6 (recognition of the ray egg capsule shown), 7 (knowledge about the ray egg capsule), and 10 (knowledge about how to differentiate between males and females), and answers different from "do not know" for questions 11 (where do they occur?) and 12 (what do they eat?) (Table 1), each weighing 1 point.

To check for differences in knowledge levels among groups, we performed a Kruskal-Wallis test, followed by the Nemenyi a posteriori test (Zar 2010), once data were not homoscedastic (Levene's test). Goodman's test (for contrasts between and within multinomial proportions) was adopted to check differences between/among the proportions of the groups that eat (or not) ray meat (Goodman 1964, 1965). Besides, we assessed the relationship between respondents' knowledge of the ray egg capsules (response variable) and the different individual responses of the three groups of respondents (explanatory variables) using Generalized Linear Models/GLM (Zuur et al. 2009, 2010) with a binomial distribution, followed by a stepwise selection method using the ordistep function (vegan package; Oksanen 2015). Permutation and AIC (Akaike Information Criterion) tests were automatically achieved by the stepwise selection model. To identify the collinear covariates, we used the VIF (Variance Inflation Factor) function of $\mathrm{R}$ car package (v.2.0-20; Fox and Weisberg 2015), and through a stepwise procedure the covariates with VIF values $<4$ were removed (O'Brien 2007). We used the bipartite package to analyze the possible correspondences between local names and scientific identification (Dormann et al. 2008). All analyses were conducted in the $\mathrm{R}$ environment ( $\mathrm{R}$ Core Team 2016) in conjunction with vegan (Oksanen et al. 2013) and ade4 (Dray and Dufour 2007) packages. We used a value of $5 \%$ significance for all statistical tests.

\section{RESULTS}

We approached 132 people, of which 22 refused to participate in the research, summing 110 interviews. Most people who refused to participate were locals and tourists. We divided the respondents into 3 groups: fishers $(n=25)$, local residents $(n=43)$, and tourists $(\mathrm{n}=42)$. We interviewed 69 men between 21 and 80 years old and 41 women between 19 and 78 years old. All fishers were male. Respondents had different professions and occupations; the most recurring ones were fisher (25), student (8), salesman (6), housekeeper (5), self-employed (5), artisan (5), teacher (4), administrator (4), painter (4); and some interviewees were retired (9). Less mentioned professions and occupations (less than three persons per occupation) were considered in the "Other" category (35).

Among the tourists, 13 people were visiting Armação beach for the first time; 4 frequented the beach daily; 14 weekly; 7 monthly; and 3 annually. Among the local residents, 12 lived in Armação from 1 to 5 years; 6 from 6 to 10 years; 4 from 11 to 15 years; 3 from 16 to 20 years; and 41 have lived in Armação for over 20 years.

We considered fishers the interviewees who use fishing as a profession (25 people). Among them, the most common type of fishing gear was bottom trawl (10), line (15), floating seine (5), and cast net (5). The other 23 respondents (local residents or tourists) considered themselves fishers, but they did not depend on this economic activity, summing 48 fishers in a broad sense. When asked if they have ever fished rays, 34 said they had fished at least once, compared with 14 who said they had never fished. About $90 \%$ of fishers stated that the bottom trawl is the fishing gears that most catch rays, followed by the line.

Most fishers said they eat rays' meat (96\%), followed by local residents (77\%) and tourists (31\%). There were significant differences in the proportion of respondents regarding the consumption of rays between and within groups (Figure 3).

\section{Local knowledge about rays}

According to the fishers, the most caught rays are "Jereva" (Gymnura sp.); "Ticonha" and "Boi", both belonging to the same taxon (Rhinoptera sp.) and "Amarela" (Sympterigia bonapartii) (Figure 4). Several local names cited by fishers correspond to the same taxa. For example, the rays of taxa Atlantoraja sp. can be recognized as "Emplastro" or "Chita/Pintada", and this latter was also cited as Aetobatus narinari. Local names were also corresponding to different taxa, as it occurs for Dasyatis sp. and Hypanus guttatus, which were also cited as "Manteiga or Prego". On the other hand, some local names are used more generically to refer to different species, such as "Emplastro", possibly referring to eight different taxa (Figure 4).

There were significant differences (Kruskal-Wallis: $\left.\mathrm{H}_{0.05 ; 2}=56.0 ; p<0.001\right)$ between the groups regarding the level of knowledge about rays. The average value of the fishers ${ }^{6}$ knowledge index was significantly higher than the other two groups (Figure 5).

After applying the stepwise analysis in the GLM, 


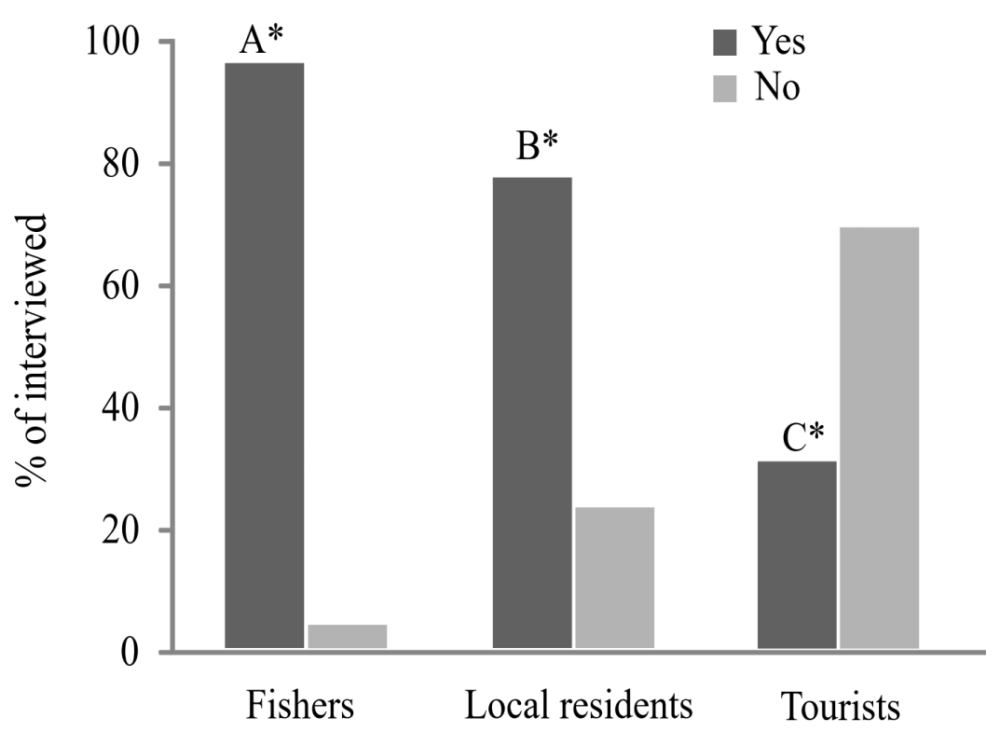

Figure 3: The proportion of respondents by groups that eat (or not) rays' meat. Different letters indicate significant differences between groups (Goodman's Test, 1964; Gcalculated $>$ Gcritic $=2.39$ ), while the asterisk $(*)$ indicates difference within each group (Goodman's Test, 1965; confidence interval does not include the zero value for Acritic $=3.84$ ).

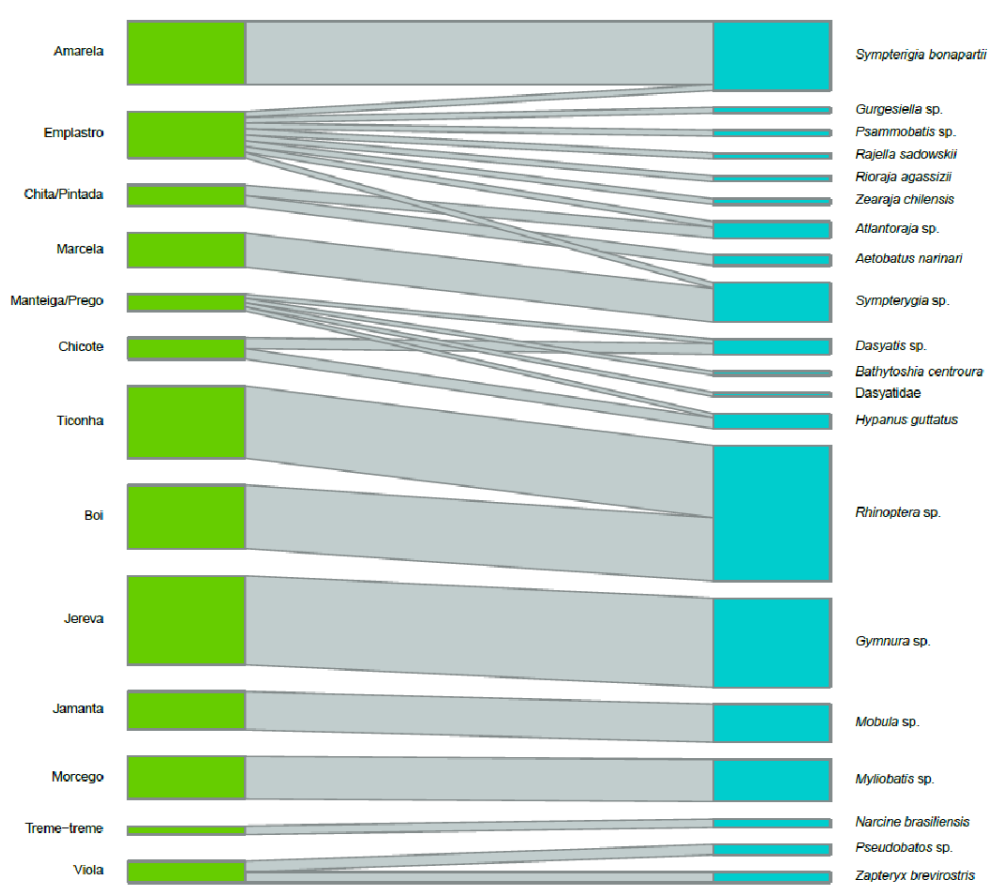

Figure 4. Number of correspondences between local names and scientific identification by the 25 fishers interviewed.

the explanatory variables "Gender" (men/women) and "Group" were the ones that most explained the model. The tourist group had a significantly lower ray egg recognition value than local residents and fishers. When it is considered the difference between genders, we have found that men (recognition value $=$
$0.60 \pm 0.06)$ is the variable that most explains the differences, with ray egg recognition values significantly higher than women $(0.19 \pm 0.06)$. Moreover, even when the group of fishers (composed only of men) was excluded from the analysis, we also found that men $(0.34 \pm 0.40)$ had significantly higher recognition 


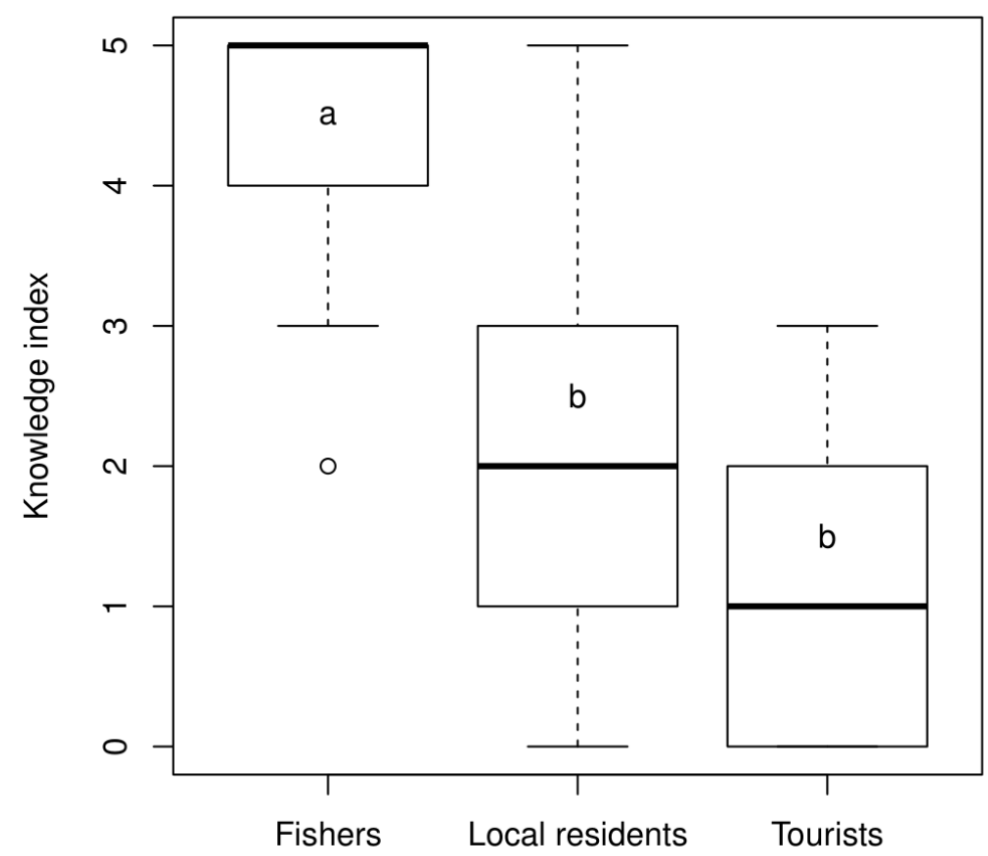

Figure 5. Values of knowledge index about rays between three different groups. Different letters indicate significant differences (Nemenyi; $p<0.05$ ).

Table 2. Summary of the GLM for recognition of ray egg capsules (110 interviews).

\begin{tabular}{cccc}
\hline \hline Source & Standard error & z value & $\mathbf{p}$ \\
\hline \hline Intercept & 0.4225 & -2.217 & $*$ \\
Fisher & 1.1063 & 2.731 & $* *$ \\
Tourist & 0.5724 & -2.803 & $* *$ \\
Gender; men & 0.5522 & 1.980 & $*$ \\
\hline \hline \multicolumn{2}{c}{ Legend: $* p<0.05, * * p<0.01$} &
\end{tabular}

values $(p<0.05)$ than women (Table 2).

The main answers about biological and ecological knowledge of the rays are summarized in Table 3. Fishers and local residents equally recognized morphological characteristics of male rays; however, no tourist mentioned such differences. Areas of occurrence usually refer to places far away from the Armação beach, such as open sea and deeper areas. Campeche Island is a coastal island close to Armação beach, widely known as a more preserved area than Santa Catarina island. Feeding habits were associated with fish, crustaceans, and other invertebrates.

\section{DISCUSSION}

Here, as expected, the fishers had a greater knowledge about the ecology and biology of rays than local residents and tourists. Although rays are not the target species of the local fishery, almost all fishers catch and consume rays. The differences observed concerning gender could be explained by the fact that all fish- ers were male and because they were closer to these animals daily. However, differences were observed even with the exclusion of fishers, and the male gender had greater knowledge. Even when fishers were excluded from the analysis, gender differences may be related to social roles men and women have regarding the domain of fish and the sea. For example, among tourists and residents in an area nearby the sea women can be more focused on aspects related to fish processing, selling, and food security (van Luijk et al. 2021). Additionally, our study was not designed to analyze gender differences in depth, but we may not ignore the fact that the interviews were made by two men authors, and the possible influence of this in the answers given by men or by women. The information that the interviewees gave regarding the feeding of the rays corroborated with the literature, which cites fish, crustaceans, and mollusks as the main components of their feeding (Carvalho-Filho 1992; Stehmann et al. 1978).

Another point to note is that the answers re- 
Table 3. Main answers of 110 interviewees about ray biology and ecology.

\begin{tabular}{|c|c|c|c|}
\hline Group & $\begin{array}{l}\text { Differences between } \\
\text { male and female rays }\end{array}$ & $\begin{array}{l}\text { Knowledge about ar- } \\
\text { eas of occurrence }\end{array}$ & $\begin{array}{l}\text { Knowledge about feed- } \\
\text { ing habits }\end{array}$ \\
\hline Fishers $(\mathrm{N}=25)$ & $\begin{array}{l}\text { The sexual organ of males } \\
\text { is visible }(100 \%)\end{array}$ & $\begin{array}{l}\text { Campeche Island (44\%), } \\
\text { open sea }(32 \%) \text {, deeper } \\
\text { areas }(16 \%) \text {, anywhere in } \\
\text { the sea }(8 \%)\end{array}$ & $\begin{array}{l}\text { Different } \\
\text { and fish }(72 \%), \text { crus- } \\
\text { taceans }(28 \%)\end{array}$ \\
\hline Local residents $(\mathrm{N}=43)$ & $\begin{array}{l}\text { The sexual organ of males } \\
\text { is bigger }(100 \%)\end{array}$ & $\begin{array}{l}\text { Deeper areas }(43 \%) \text {, open } \\
\text { sea }(38 \%) \text {, Campeche is- } \\
\text { land }(19 \%)\end{array}$ & $\begin{array}{l}\text { Fish }(36 \%) \text {, crustaceans } \\
(36 \%) \text {, different inverte- } \\
\text { brates and fish }(28 \%)\end{array}$ \\
\hline Tourists $(\mathrm{N}=42)$ & Do not know & $\begin{array}{l}\text { Open sea }(68 \%) \text {, deeper } \\
\text { areas }(32 \%)\end{array}$ & $\begin{array}{l}\text { Fish }(62 \%) \text {, different in- } \\
\text { vertebrates and fish }(38 \%)\end{array}$ \\
\hline
\end{tabular}

garding rays' occurrence were very similar among the groups but were more diverse, complete, and in agreement with the scientific literature (Michael 1993) in the group of fishers. For the other two groups, the answers were vague and not detailed. Answers as "high seas" and "deep regions" were more common for residents and tourists than for fishers. Tourists were more unaware of rays in shallow regions and not as far from the human population as they believe. However, it is the case of the species Gymnura altavela (5-100 m deep), Myliobatis goodei (1-130 m), and Dasyatidae species (0-53 m) (Bernardes et al. 2005; Brito 1991; Uyeno et al. 1983).

According to the fishers, bottom trawling is the gear that captures most rays. However, these types of nets intercept neonates and juveniles' distribution areas, especially in shallow coastal waters and the continental shelf, respectively, with no refuge for elasmobranchs (Kotas et al. 2008; Vooren and Klippel 2005). As noted earlier, elasmobranchs' peculiar characteristics (e.g., slow growth, low fecundity, and late maturation) make them more vulnerable to overfishing, reaching the point of collapse if no measures are adopted (Camhi et al. 2009; ICMBIO 2016; SBEEL 2005; Vooren 1997). Also, fishers report that this type of net catches several other organisms (such as octopuses, squids, non-commercial fishes, and small invertebrates) that are sometimes thrown overboard dead, but they may also be consumed. Thus, the regulations for using this type of fishing gear must be more enforced by the Brazilian government, once it is well known the negative impacts for elasmobranch populations (Stevens et al. 2000; Zeller et al. 2018). This is even more worrying due to the high number of endangered species and the high level of endemism in this region (Dulvy et al. 2014; Lucifora et al. 2011).

Interestingly, many of these species cannot be captured according to Brazilian Ordinance 445/2014 (Brasil 2014), but environmental monitoring is ineffective. This seems to be true that in our work, both fishers and the resident population usually eat rays.
Although the trade of ray species in Santa Catarina does not occur on a large scale compared to sharks (Almerón-Souza et al. 2018; Cruz et al. 2021), the present study shows that local consumption is appreciated. Due to the rays coming from bycatch and their sale is mainly restricted by the Brazilian law, they end up being for their own consumption and what they can sell they do. Furthermore, the sale and consumption may be occurring before the specimens arrive in large commercial markets, and these practices can impact some populations. It is important to note that the risk of extinction of all possible species analyzed in this study requires attention (out of 45 ray species, 7 are CR, 5 are EN, 13 are VU, 5 are NT, 4 are LC and 11 are DD; Hayata et al. 2018).

Increasing international demand for meat from several rays, such as the Rajidae family, has led to an increase in the fishing intensity of these "fish meat" (Mazzoleni and Schwingel 1999). Elasmobranch meat (rays and sharks) is sold as "cação" in both restaurants and markets (Bornatowski et al. 2013). Previous studies showed that fisheries, markets owners and restaurants generally omit information when they were selling "cação" meat (MPA 2011; Bornatowski et al. 2015). Moreover, the Brazilian markets often encourage people to eat this meat, due to its attractive price and to avoid meat waste (Bornatowski et al. 2018). Thus, the low value of $36 \%$ of tourists that eat rays is underestimated, and many people probably are unaware of which species they are really consuming. Bornatowski et al. (2015) also showed that most consumers do not know that "cação" is associated with shark and ray meat in a big city of southern Brazil. The consumers do not even know they had ever eaten shark or ray. In the neighboring state of Santa Catarina, Paraná, Bernardo et al. (2020) found that the ray Pseudobatos percellens was the most commercialized species under the label of "cação". Moreover, $62 \%$ of fish sold as groupers in two states of Brazil (São Paulo and Rio de Janeiro) are in fact sharks (Estrella et al. 2014). Independently, this mislabeling 
can make it impossible for consumers to make decisions about the consumption of elasmobranch meat, interfering with efforts to reduce such consumption (Bornatowski et al. 2013). This meat also has high levels of heavy metals, bringing substantial risks for human health (Lopez et al. 2013). Our study showed that the sale of ray meat is an everyday activity in Armação beach. This situation is even more alarming because little is known about the conservation status of several species in Brazil, and an assessment of their fishing potential has not been made (Haimovici et al. 2008). It is important to note that in the state of São Paulo (near to Santa Catarina and with similar ray fauna and fishing characteristics), $44.3 \%$ of batoids species caught are threatened and included in IUCN Red List, and $57.47 \%$ were protected by law in Brazil (Ferrete et al. 2019). Hence, it is of great importance improve the knowledge of the people about the elasmobranch ecology and risks of consuming these organisms for human health (Bornatowski et al. 2015).

According to the Brazillian Ministry of Environment, several cited ray species (correlated to their folk names) are currently on the Official National List of Endangered Fauna Species, and they belong to the genera: Atlantoraja, Dasyatis, Gymnura, Mobula, Myliobatis, Pseudobatos, Rioraja, Sympterygia, Zapteryx. Species on the List are classified in the Critically Endangered (CR), Endangered (EN) and Vulnerable (VU) categories and are fully protected, including the prohibition of capture, transport, storage, handling, processing, and the marketing (MMA 2014). Despite the existence of a legal instrument, there is a growing fishing effort due to the number of vessels, technological enhancement, and ineffective oversight by fisheries management bodies (Occhialini et al. 2012). In addition, the demand (consumption) of rays is mainly supplied by the bycatch (Dulvy et al. 2014; Ferrete et al. 2019) and therefore, even if fishing for rays is not the commercial target, they will still be impacted if not regulated and monitored according to the laws.

It is important to highlight the great knowledge that fishers have about the biology and ecology of the fish caught, since the information of this nature may be essential for fisheries control (Marques 2001) and management of fish stocks. This increased knowledge of such organisms is doubly adaptive because it can contribute to more cost-effective and profitable fishing (Barbosa-Filho et al. 2014) and sustainable fishing. On the other hand, there is a great lack of tourists' awareness on this group of animals, even in basic issues such as the differentiation between males and females, evidencing the need for knowledge about the role of elasmobranchs in the marine environment to be disseminated (Garla et al. 2015).

Since the integration of academic and locally con- structed knowledge favors a contextualized analysis (Carlsson and Berkes 2005), the present study can accordingly be used. We found that several local names of rays correspond to the same taxon. The same situation also occurred with sharks in other states of the Brazilian coast (Barbosa-Filho et al. 2021; Carvalho et al. 2018). These authors found that approximately 3 to 5 local names of sharks belonged to the same taxon. In addition, Barbosa-Filho et al. (2021) highlighted that some sharks might have more than ten folk names, but usually, one or two are the most usual. A folk name can also indicate more than one species, as occurred for "Emplastro" in our work and "cação-panã" in the northeastern Brazilian coast (Carvalho et al. 2018). Once Fishery Statistics no longer exist in a controlled manner in Brazil since 2011, this problem is a major challenge. Because even using the folk names sold in fish markets will not accurately inform which species are being more or less captured, but it could help to provide a slightly more accurate picture than just a statistic based on local names such as "cação" and ray. It is suggested that the folk names of elasmobranch species may be a great way for the integration between fishers and government actions as well as in advances for conservation and management plans (Barbosa-Filho et al. 2021; Carvalho et al. 2018).

\section{CONCLUSION}

Our study showed that the fishers' group presented most knowledge regarding the ecology and biology of rays and was the group with higher awareness about the consumption of these organisms. The rays are part of a group of fish of interest for consumption, although not a target of local fishing. At the same time, due to their biological characteristics, the rays' conservation status requires attention since their stocks can be easily compromised. The gender related differences we found suggest that the topic should be further investigated, especially among the group of non-fishers (residents and tourists), for a better understanding on how people interact with rays and, if there are conservation concerns, how different segments of the public may be approached. To avoid the negative effects of ray catches on their populations, a better disclosure to society about the degree of conservation and the importance of rays on trophic balance and ecosystem health is needed. We also identified a need to avoid the mislabelling of ray meat that is probably being sold in restaurants to better understand the consumption pressure over these species. 


\section{ACKNOWLEDGEMENT}

We thank the management of Lagoa do Peri Municipal Park and its staff, and to M.F. Hornke for logistic support for data collection, to E.L.H. Giehl, A.M. Machado, and C.J. Decarli for contributions in analysis. We also thank all respondents who agreed to participate. N.H. thanks to $\mathrm{CNPq}$ for a research productivity scholarship (309613/2015-9). This study was financed in part by the Coordenação de Aperfeiçoamento de Pessoal de Nível Superior - Brasil (CAPES) - Finance Code 001.

\section{DATA AVAILABILITY}

The data used to support the findings of this study are available from the corresponding author upon reasonable request.

\section{CONFLICT OF INTEREST}

The authors have no conflicts of interest to declare.

\section{CONTRIBUTION STATEMENT}

Conceived of the presented idea: RFF, LPM, RHAF, $\mathrm{NH}$

Carried out the experiment: RFF, LPM

Carried out the data analysis: RFF, LPM, RHAF, $\mathrm{NH}$

Wrote the first draft of the manuscript: RFF, LPM, RHAF, NH

Review and final write of the manuscript: RFF, LPM, RHAF, NH

Supervision: RFF, RHAF, NH

\section{REFERENCES}

Aguiar AA, Valentin JL (2010) Biologia e ecologia alimentar de elasmobrânquios (Chondrichthyes: Elasmobranchii): Uma revisão dos métodos e do estado da arte no Brasil.org/. Oecologia Australis doi: 10.4257/oeco.2010.1402.09. Almerón-Souza F, Sperb C, Castilho CL, Figueiredo PI, Gonçalves LT, Machado R, Oliveira LR, Valianti VH, Fagundes NJ (2018) Molecular Identification of Shark Meat From Local Markets in Southern Brazil Based on DNA Barcoding: Evidence for Mislabeling and Trade of Endangered Species. Frontiers in genetics doi: 10.3389/fgene.2018.00138.

Barbosa-Filho MLV, Schiavetti A, Alarcon DT, Costa Neto EM (2014) 'Shark is the man!': ethnoknowledge of Brazil's South Bahia fishermen regarding shark behaviors. Journal of Ethnobiology and Ethnomedicine doi: 10.1186/1746-4269-1054.

Barbosa-Filho MLV, Ramires M, da Silva Mourão J, de Souza Rosa R, Alves RRN, Costa-Neto EM (2021) Ethnotaxonomy of sharks by expert fishers from South Bahia, Brazil: Implications for fisheries management and conservation. Ethnobiology and Conservation doi: 10.15451/ec2021-08-10.02-1-12.

Begossi A, Salivonchyk SV, Araujo LG, Andreoli TB, Clauzet M, Martinelli CM, Ferreira AG, Oliveira LE, Silvano RA (2011) Ethnobiology of snappers (Lutjanidae): target species and suggestions for management. Journal of Ethnobiology and Ethnomedicine doi: 10.1186/1746-4269-7-11.

Begossi A, Salyvonchyk S, Nora V, Lopes PF, Silvano RA (2012) The Paraty artisanal fishery (southeastern Brazilian coast): ethnoecology and management of a social-ecological system (SES). Journal of Ethnobiology and Ethnomedicine doi: 10.1186/1746-4269-8-22.

Berkes FE, Folke C (2000) Linking social and ecological systems for resilience and sustainability. In: Berkes F, Folke C (eds) Linking social and ecological systems: management practices and social mechanisms for building resilience. Cambridge University Press, Cambridge, UK, pp. 1-26.

Bernardes RÁ, Figueiredo JL, Rodrigues AR, Fischer LG, Vooren CM, Haimovici M, Rossi-Wongtschowski CLDB (2005) Peixes de zona econômica exclusiva da região sudeste-sul do Brasil: Levantamento com armadilhas, pargueiras e rede de arrasto de fundo. Editora da Universidade de São Paulo, São Paulo, Brazil.

Bernardo C, de Lima Adachi AMC, da Cruz VP, Foresti F, Loose RH, Bornatowski H (2020) The label "Cação" is a shark or a ray and can be a threatened species! Elasmobranch trade in Southern Brazil unveiled by DNA barcoding. Marine Policy doi: 10.1016/j.marpol.2020.103920.

Bornatowski H, Abilhoa V (2012) Tubarões e raias capturados pela pesca artesanal no Paraná: guia de identificação. 1 ed. Hori Consultoria Ambiental, Curitiba, Brazil.

Bornatowski H, Braga RR, Vitule JRS (2013) Shark Mislabeling Threatens Biodiversity. Science doi: 10.1126/science.340.6135.923-a.

Bornatowski, H, Braga, RR, Kalinowski, C, Vitule, JRS (2015) "Buying a pig in a poke": the problem of elasmobranch meat consumption in Southern Brazil. Ethnobiology Letters doi: 


\subsection{7/ebl.6.1.2015.451.}

Bornatowski, H, Braga, RR, Barreto, RP (2018) Elasmobranchs Consumption in Brazil: Impacts and Consequences. In: Rossi-Santos M, Finkl C (eds) Advances in Marine Vertebrate Research in Latin America. Coastal Research Library. Springer International Publishing, Cham, Vol 22, pp. 251-262.

Brasil. Ministério do Meio Ambiente (2014) Lista Nacional Oficial de Espécies da Fauna Ameaçadas de Extinção - Peixes e Invertebrados Aquáticos. Portaria MMA n. 445, de 17 de dezembro de 2014.

Brito A (1991) Catalogo de los pesces de las Islas Canarias. Francisco Lemus, la Laguna.

Camhi M, Fowler S, Musick J, Bräutigam A, Fordham S (1998) Sharks and their relatives: Ecology and Conservation. Occasional Paper of the IUCN Species Survival Commission Occas. Pap. No. 20.

Camhi MD, Vale SV, Fordham SV, Fowler SL, Gibson C (2009) The Conservation Status of Pelagic Sharks and Rays: Report of the IUCN Shark Specialist Group Pelagic Shark. Red List Workshop. IUCN Species Survival Commission Shark Specialist Group, Newbury, UK.

Carlsson L, Berkes F (2005) Co-management: concepts and methodological implications. Journal of Environmental Management doi: 10.1016/j.jenvman.2004.11.008.

Carvalho-Filho A (1992) Peixes: costa Brasileira. Marca d'água, São Paulo, Brazil.

Carvalho MM, Oliveira, MR, Lopes PFM, Oliveira JEL (2018) Ethnotaxonomy of sharks from tropical waters of Brazil. Journal of ethnobiology and ethnomedicine doi: 10.1186/s13002-018-0273-0.

Castro JL (1983) Sharks of the North American Waters. 1 ed. University Press, Texas A \& M.

Costa L, Chaves PTC (2006) Elasmobrânquios capturados pela pesca artesanal na costa sul do Paraná e norte de Santa Catarina, Brasil. Biota Neotropica doi: 10.1590/S1676-06032006000300007.

Cruz VP, Adachi AMCL, Ribeiro GS, Oliveira PH, Oliveira C, Oriano Junior R, Freitas RHA, Foresti F (2021) A shot in the dark for conservation: Evidence of illegal trade of endemic and threatened species of elasmobranch in public market at Southern Brazil. Aquatic Conservation: Marine and Freshwater Ecosystems doi: 10.1002/aqc.3572.

Dias-Neto D (2011) Proposta de Plano Nacional de Gestão para o uso sustentável de elasmobrânquios sobre-explotados ou ameaçados de sobreexplotação no Brasil. Brasília: IBAMA, 2011.

Diegues AC, Arruda RSV, Silva VCF, Figols FAB, Andrade D (2000) Biodiversidade e comunidades tradicionais no Brasil - Os Saberes tradicionais e a biodiversidade no Brasil. Ministério do Meio Ambiente, dos Recursos Hídricos e da Amazônia Legal. COBIO - Coordenadoria da Biodiversidade. NUPAUB- Núcleo de pesquisas sobre populações humanas e áreas úmidas. São Paulo, Brazil.

Dormann CF, Gruber B, Fruend J (2008) Introducing the bipartite Package: Analysing Ecological Networks. ISSN 1609-3631.

Dray S, Dufour AB (2007) The ade4 package: implementing the duality diagram for ecologists. Journal of Statistical Software doi: 10.18637/jss.v022.i04.

Dulvy NK, Fowler SL, Musick JA, Cavanagh RD, Kyne PM, Harrison LR, Carlson JK, et al. (2014) Extinction risk and conservation of the world's sharks and rays. eLife doi: 10.7554/eLife.00590.

Ellis JR, Pawson MG, Shackley SE (1996) The comparative feeding ecology of six species of shark and four species of ray (Elasmobranchii) in the north-east Atlantic. Journal of Marine Biological Association of the UK doi: $10.1017 /$ S0025315400029039.

Estrella F, Raposo G, Pascolli J, Gonzalez JG, Motta FS, Moura RL (2014) Comercialização de pescado nas cidades de São Paulo e Rio de Janeiro. https://wwwsosmaorgbr/wpcontent/uploads/2014/09/ESTUDO-PESCADO-

2014_Relatorio-Final.pdf Accessed 21 April 2021.

Ferrette BLS, Domingues RR, Rotundo MM, Miranda MP, Bunholi IV, De Biasi JB, Oliveira C, Foresti F, Mendonça FF (2019) DNA barcode reveals the bycatch of endangered batoids species in the south-west atlantic: implications for sustainable fisheries management and conservation efforts. Genesn doi: 10.3390/genes10040304.

Fox J, Weisberg S (2015) Car: Companion to Applied Regression $R$ Package 2015. version $\mathbf{2 . 0 - 2 0}$. https://cran.rproject.org/web/packages/car/index.html Accessed 31 July 2020.

Goodman LA (1964) Simultaneous confidence intervals for contrast among multinomial populations. Annals of Mathematical Statistics doi: 10.1214/aoms/1177703569. Garla RC, Fre- 
itas RHA, Calado JF, Paterno GBC, Carvalho AR (2015) Public awareness of the economic potential and threats to sharks of a tropical oceanic archipelago in the western South Atlantic. $M a-$ rine Policy doi: 10.1016/j.marpol.2015.06.012.

Goodman LA (1965) On simultaneous confidence intervals for contrast among multinomial proportions. Technometrics doi: 10.1080/00401706.1965.10490252.

Gomes UL, Signori C, Gadig OBF, Santos HRS (2010) Guia para identificação de tubarões e raias do Rio de Janeiro. 1 ed. Technical Books Editora, Rio de Janeiro, Brazil.

Haimovici M, Rossi-Wongtschowscki CLDB, Bernardes, RA, Fischer LG, Vooren CM, Dos Santos RA, Rodrigues AR, Santos S (2008) Prospecção pesqueira de espécies demersais com rede de arrasto-de-fundo na Região Sudeste-Sul do Brasil. Instituto Oceanográfico-USP/Série Documentos REVIZEE, São Paulo.

Hayata MA, Mayer GB, Soares LE, d'Avila MG, Hornke MF, Freitas RHA (2018) O grupo dos elasmobrânquios. In: Martins TM, Tomazi AL, Brenuvida WW (eds) A importância dos elasmobrânquios para a qualidade dos ecossistemas marinhos a partir do conhecimento local. 1ed. Editora 3 de Maio, Baía de Tijucas, pp. 51-79.

Hanazaki N, Freitas RR (2011) Etnoecologia, educação e meio ambiente. In: Arruda VLV, Hanazaki $\mathrm{N}$ (eds) Tecendo reflexões em educação e meio ambiente. UFSC, Florianópolis, pp. 45-58.

Heithaus A, Frid A, Wirsing AJ, Worm B (2008) Predicting the ecological consequences of marine top predator declines. Trends in Ecology 85 Evolution doi: 10.1016/j.tree.2008.01.003.

IBGE - Instituto Brasileiro de Geografia e Estatística (2011) Sinopse do Senso Demográfico de 2010. Rio de Janeiro, Brazil.

Instituto Chico Mendes - ICMBIO (2016) Avaliação do risco de extinção dos elasmobrânquios e quimeras no Brasil: 20102012. http://www.icmbio.gov.br Accessed 31 July 2020 .

IUCN (2010) Guidelines for application of IUCN Red List criteria at regional and national levels: version 4.0. Prepared by the IUCN Species Survival Comission.

IUCN (2014) Guidelines for Using the IUCN Red List Categories and Criteria. Version 11. Prepared by the Standards and Petitions Subcommittee.
Kimmerer RW (2002) Weaving traditional ecological knowledge into biological education: a call to action. BioScience doi: 10.1641/00063568(2002)052[0432:WTEKIB]2.0.CO;2.

Kotas JE, Petrere Jr M, Fiedler F, Mastrochirico V, Sales G (2008) A pesca de emalhe-de-superficie de Santa Catarina direcionada à captura dos tubarões martelo, Sphyrna lewini (Griffith and Smith 1834) e Sphyrna zygaena (Linnaeus 1758). Atlântica doi: 10.5088/atlântica.v30i2.1511.

Last P, Naylor G, Séret B, White W, Stehmann M, Carvalho M (2016) Rays of the world. Csiro Publishing, Australia.

Lopez SA, Abarca NL, Meléndez R (2013) Heavy metal concentrations of two highly migratory sharks (Prionace glauca and Isurus oxyrinchus) in the Southeastern Pacific waters: comments on public health and conservation. Tropical Conservation doi: $10.1177 \% 2 \mathrm{~F} 194008291300600103$.

Lucifora LO, García VB, Worm B (2011) Global diversity hotspots and conservation priorities for sharks. PloS one doi: 10.1371/journal.pone.0019356.

Marques JGW (2001) Pescando Pescadores: Etnoecologia abrangente no baixo São Francisco Alagoano. NUPAUB/USP, São Paulo, Brazil.

Martins IM, Medeiros RP, Hanazaki N (2014) From fish to ecosystems: The perceptions of fishermen neighboring a southern Brazilian marine protected area. Ocean \& coastal management doi: 10.1016/j.ocecoaman.2014.01.015.

Martins IM, Medeiros RP, Di Domenico M, Hanazaki N (2018) What fishers' local ecological knowledge can reveal about the changes in exploited fish catches. Fisheries research doi: 10.1016/j.fishres.2017.10.008.

Mazzoleni RC, Schwingel PR (1999) Elasmobranch species landed in Itajaí harbor (southern Brazil). Notas Técnicas FACIMAR doi: 10.14210/bjast.v3n1.p111-118.

Michael SW (1993) Reef sharks and rays of the world. A guide to their identification, behavior, and ecology. Sea Challengers, Monterey, California.

Ministério do Meio Ambiente, Portaria № 445 DE 17 DE DEZEMBRO DE 2014. Available at: http://www.icmbio.gov.br/cepsul/images/ stories/legislacao/Portaria/2014/p_mma_445_ 2014_lista_peixes_amea\%C3\%A7ados_extin\%C3\% 
A7\%C3\%A3o.pdf. Accessed 15 January 2017.

MPA. Boletim estatístico da pesca e aquicultura (2011) Relatório do Ministério da Pesca e Aquicultura, 98. http://www.icmbio. gov.br/cepsul/images/stories/biblioteca/ download/estatistica/est_2011_bol__bra.pdf] Accessed21Apri12021.

Musick JA (2005) Introduction. In: Fowler SL, Cavanagh, RD, Camhi M, Burgess GH, Cailliet GM, Fordham SV, Simpfendorfer CA, Musick JA. (eds) Sharks, rays and chimaeras: the status of the chondrichthyan fishes. Status Survey. IUCN/SSC Shark Specialist Group Gland, Switzerland and Cambridge, pp. 1-3.

O'Brien RM (2007) A Caution Regarding Rules of Thumb for Variance Inflation Factors. Quality $\&$ Quantity doi: 10.1007/s11135-006-9018-6.

Occhialini DS, Rodrigues AMT, Kotas JE (2012) Caracterização e análise comparativa da pesca industrial de emalhe-de-fundo costeiro, considerando a evolução física da frota a partir de 1995 e a produção pesqueira entre 2001 e 2010. Revista CEPSUL - Biodiversidade e Conservação Marinha 3:1-21.

Oksanen J, Blanchet FG, Kindt R, Oksanen MJ, Suggests M (2013) Package 'vegan'. Community ecology package Version 2, 0-0. https:// cran.ism.ac.jp/web/packages/vegan/vegan.pdf Accessed 29 July 2020.

Oksanen J (2015) Multivariate Analysis of Ecological Communities in R: Vegan Tutorial. http://cc.oulu.fi/ jarioksa/opetus/ metodi/vegantutor.pdf Accessed 31 July 2020.

Palmeira ARO (2012) Biologia reprodutiva da raia Dasyatis guttata (Bloch and Schneider, 1801) (Myliobatiformes: Dasyatidae) no litoral do Pará. MSc. dissertation, UFPB, João Pessoa, Brazil.

Pereira BE, Diegues AC (2010) Conhecimento de populações tradicionais como possibilidade de conservação da natureza: uma reflexão sobre a perspectiva da etnoconservação. Desenvolvimento e Meio Ambiente doi: 10.5380/dma.v22i0.16054.

Peterson D, Berkes F, Davidson-Hunt I, Hanazaki N (2019) The Caiçara in Juatinga Ecological Reserve, Brazil: Landscape Ethnoecology of Cultural Products. Human Ecology doi: 10.1007/s10745-019-00126-3.

Porcher LCF, Poester G, Lopes M, Schonhofen P, Silvano RAM (2010) Percepção dos moradores sobre os impactos ambientais e as mudanças na pesca em uma lagoa costeira do litoral sul do Brasil. ftp://ftp.sp.gov.br/ftppesca/36_1_ 61-72.pdf Accessed 31 July 2020.

R Core Team (2016) R: a Language and Environment for Statistical Computing. $\mathrm{R}$ Foundation for Statistical Computing, Vienna, Austria. https://www.R-project.org Accessed 29 July 2020.

Rosa RS, Gadig OBF (2014) Conhecimento da diversidade dos Chondrichthyes marinhos no Brasil: a contribuição de José Lima de Figueiredo. Arquivos de Zoologia. Museu de Zoologia da Universidade de São Paulo doi: 10.11606/issn.2176-7793.v45iespp89-104.

SBEEL - Sociedade Brasileira para o estudo de elasmobrânquios (2005) Plano Nacional de ação para a conservação e o manejo dos estoques de peixes elasmobrânquios no Brasil. SBEEL, Recife.

Santos MC, Faria-Junior E, Freitas RHA (2019) Reconhecimento etnoecológico sobre o tubarão-mangona Carcharias taurus sob a perspectiva de pescadores artesanais da grande Florianópolis-SC, Brasil. Revista Nordestina de Biologia doi: 10.22478/ufpb.22361480.2019v27n1.47526.

Stehmann M, McEachran JD, Vergara R (1978) Dasyatidae. In: Fischer W (ed) FAO species identification sheets for fishery purposes. Western Central Atlantic (Fishing Area 31). Vol. 1. [pag. var.], FAO, Rome.

Stevens JD, Bonfil R, Dulvy NK, Walker PA (2000) The effects of fishing on sharks, rays and chimaeras (chondrichthyans), and the implications for marine ecossystems. ICES Jorurnal of Marine Science doi: 10.1006/jmsc.2000.0724.

Thaman RR (1994) Marine Ethnobiology: a foundation for marine science education in the Pacific Islands. Department of Education and The Institute of Education, The University of the South Pacific, Suva, Fiji.

Uyeno T, Matsuura K, Fujii E (1983) Fishes trawled off Suriname and French Guiana. Japan Marine Fishery Resource Research Center, Tokyo, Japan.

van Luijk N, Silva ZM, Oliveira MH, Fonseca-Kruel VS (2021) Mulheres e a pesca artesanal: salvaguardando conhecimentos tradicionais sobre plantas da restinga em Arraial do Cabo, Brasil. Ethnoscientia doi: 10.22276/ethnoscientia.v6i2.388.

Vaudo JJ, Heithaus MR (2011) Dietary niche over- 
lap in a nearshore elasmobranch mesopredator community. Marine Ecology Progress Series doi: 10.3354/meps08988.

Vooren CM (1997) Demersal elasmobranchs. In: Seeliger U, Odebrecht C, Castello JP (eds) Subtropical convergence environment: the coast and the sea in the Southwestern Atlantic. Springer, Berlim, pp. 41-146.

Vooren CM, Klippel S (2005) Ações para a conservação de tubarões e raias no sul do Brasil. Igaré, Porto Alegre.

Zar JH (2010) Biostatistical analysis. Prentice Hall, Englewood Cliffs, NJ.

Zeller D, Cashion T, Palomares M, Pauly D (2018) Global marine fisheries discards: A synthesis of reconstructed data. Fish and Fisheries doi: 10.1111/faf.12233.

Zuur AF, Ieno EN, Walker NJ, Saveliev AA, Smith GM (2009) Mixed effects models and extensions in ecology with R. Springer, New York, NY.

Zuur AF, Ieno EN, Elphick S (2010) A protocol for data exploration to avoid common statistical problems. Methods in Ecology and Evolution doi: 10.1111/j.2041-210X.2009.00001.x.

Received: 17 September 2020 Accepted: 10 May 2021 Published: 24 May 2021 